\title{
PENGGUNAAN MEDIA KARTU PERMAINAN UNTUK MENINGKATKAN HASIL BELAJAR MEMBACA HURUF HIJAIYAH DAN HARAKAT KELAS I SD MUHAMMADIYAH PANJI
}

\author{
Mory Victor Febrianto ${ }^{1)}$ \\ 1) Universitas Abdurachman Saleh Situbondo \\ mory_victor86@yahoo.com
}

\begin{abstract}
ABSTRAK: Penelitian ini bertujuan untuk meningkatkan kemampuan membaca huruf hijaiyah melalui metode permainan kartu surat di 1 SDN Panji Muhammadiyah. Jenis penelitian ini adalah penelitian tindakan kelas dengan menggunakan model penelitian Kemmis dan Mc Model PTK. Penelitian ini menggunakan mata pelajaran kelas 1 sekolah dasar Muhammadiyah 1 Panji, yang berjumlah 23 anak. Objek penelitian ini berfokus pada peningkatan kemampuan membaca surat dan hadiah hijaiyah melalui media bermain kartu surat. Metode pengumpulan data menggunakan observasi daftar periksa, wawancara, tes dan dokumentasi. Data dianalisis menggunakan teknik deskriptif persentase. Hasil penelitian menunjukkan bahwa ada peningkatan kemampuan membaca awal dalam pra-siklus penelitian dengan 23 subjek penelitian, ada 13 siswa atau 57\% telah mencapai ketuntasan sedangkan 10 atau $43 \%$ belum mencapai ketuntasan. Setelah melakukan penelitian dengan menggunakan metode permainan kartu surat pada siklus pertama ada peningkatan dengan 18 siswa atau $78 \%$ siswa yang menyelesaikan sementara 5 siswa atau $22 \%$ tidak selesai. dan pada siklus II meningkat lagi dengan semua siswa atau $100 \%$ siswa menyelesaikan dan .. Langkah-langkah implementasi yang digunakan untuk meningkatkan kemampuan membaca huruf hijaiyah dan hadiah anak-anak adalah dengan menggunakan media permainan kartu kartu, guru memberikan penjelasan tentang surat-surat hijaiyah, dan memberikan apresiasi verbal dan tepuk tangan kepada siswa yang bisa.
\end{abstract}

Kata kunci : Hasil Belajar IPA, Kecerdasan Sosial.

ABSTRACT: This study aims to improve the ability to read hijaiyah letters through the letter card game method in 1 Panji Muhammadiyah Primary School. This type of research is classroom action research using the Kemmis and Mc Model PTK research model. This study used the subject of grade 1 Muhammadiyah 1 Panji elementary school, amounting to 23 children. The object of the study focuses on improving the ability to read hijaiyah letters and gifts through the media playing letter cards. The method of collecting data uses checklist observation, interviews, tests and documentation. Data were analyzed using percentage descriptive techniques. The results showed that there was an increase in the ability to read early in pre-cycle research with 23 research subjects, there were 13 students or $57 \%$ had achieved completeness while 10 or $43 \%$ had not achieved completeness. After conducting research using the letter card game method in the first cycle there was an increase with 18 students or $78 \%$ of students who completed while 5 students or $22 \%$ were not completed. and in cycle II it increases again with all students or $100 \%$ students completing and.. Implementation steps that are used to improve the ability to read the letters hijaiyah and the children's gift is by using letter card game media, the teacher gives an explanation of the letters hijaiyah, and giving verbal appreciation and applause to students who can.

Keywords: Media Game, Hasil Belajar Dan Huruf Hijaiyah

\section{PENDAHULUAN}

Perubahan kurikulum di Indonesia membuat guru semakin dituntut untuk selalu berperan aktif dalam mengembangkan pengajaran. Sekolah dasar menjadi tempat pijakan 
awal bagi seorang anak didik untuk belajar memahami. Sekolah dasar merupakan salah satu lembaga pendidikan formal yang mempelajari apa itu Agama, apa itu pengetahuan alam dan sebagainya. Penanaman konsep awal yang salah akan mempengaruhi perkembangan minat serta motivasi anak didik dalam menapaki jenjang pendidikan yang lebih tinggi.

Rendahnya kualitas pendidikan dapat diartikan sebagai kurang berhasilnya suatu proses pembelajaran di suatu lingkungan pendidikan. Pada umumnya, faktor rendahnya tingkat keberhasilan dalam pembelajaran disebabkan oleh faktor dari siswa itu sendiri, faktor dari guru, tidak adanya media pembelajaran yang digunakan, serta penggunaan metode pembelajaran yang kurang tepat. Jika hal ini dibiarkan, maka tidak menutup kemungkinan akan timbul rendahnya minat, motivasi, dan kemampuan siswa terhadap pelajaran Baca Tulis Al-Quran (BTQ).

Baca Tulis Al-Quran (BTQ) dipandang sebelah mata, karena dianggap mudah dan bisa dipelajari di musollah. Padahal dari penjelasan guru kelas 1 di SD 1 Muhammadiyah bahwa sebagian anak-anak belum secara benar membaca huruf hijaiyah dengan baik sesuai kaidah bacaan yang benar. Anak-anak kelas satu masih memiliki kekurangan dalam penguasaan materi menghafal huruf-huruf hijaiyah dan harakat.

Secara spesifik masalah yang berhasil diidentifikasi dalam pembelajaran matematika di SD 1 Muhammadiyah adalah penentuan penerapan metode dalam pembelajaran Baca Tulis Al-Quran (BTQ) masih dianggap cukup menyulitkan oleh kebanyakan siswa, serta kurang menariknya penggunaan media pembelajaran dalam proses belajar mengajar, karena ketidaksiapan guru dalam membuat media dengan alasan waktu yang terbatas. Hal tersebut sangat berdampak terhadap hasil belajar siswa pada mata pelajaran Baca Tulis Al-Quran (BTQ) Nilai Baca Tulis Al-Quran (BTQ).sebagai skor awal peneliti yang diambil dari hasil ulangan pada materi sebelumnya/sebelum tindakan, menunjukkan bahwa persentase hasil belajar siswa masih rendah yaitu 57\% atau hanya 13 siswa dari 23 siswa yang tuntas hasil belajarnya.

Berdasarkan hasil wawancara dengan guru, diketahui bahwa guru menemukan kesulitan dalam pemilihan atau menentukan metode yang akan diterapkan pada saat menyusun RPP dan ketidaksiapan guru dalam membuat media. Sehingga, guru sering menerapkan metode ceramah tanpa menggunakan media yang menarik. Guru hanya menjelaskan konsep-konsep perkalian di papan tulis. Hasil wawancara dengan siswa, diketahui bahwa siswa merasa jenuh pada saat pembelajaran. Pada awal pembelajaran siswa sangat antusias untuk belajar. Namun semakin lama, suasana kelas semakin membosankan. Dengan demikian, dapat diketahui akar masalah atau pokok permasalahan dari rendahnya hasil belajar siswa yaitu selain penerapan metode yang kurang tepat, juga kurangnya penggunaan media pembelajaran sehingga siswa menjadi bosan dan mengalami kesulitan dalam memahami materi.

Pemecahan masalah dari hasil identifikasi dan analisis masalah di atas yaitu dengan melakukan perbaikan dalam proses pembelajaran Baca Tulis Al-Quran (BTQ) pokok 
bahasan hijaiyah dan harakat, sehingga diharapkan dapat meningkatkan aktivitas dan hasil belajar siswa.

\section{KAJIAN PUSTAKA}

Kata media merupakan bentuk jamak dari medium. Kata itu berasal dari bahasa latin "medius" yang artinya tengah. Dalam kamus bahasa Indonesia, kata medium artinya antara. Secara harfiah kata media berarti perantara atau pengantar.

Secara lebih khusus, pengertian media dalam proses pembelajaran cenderung diartikan sebagai alat-alat grafis, photografis, atau elektronis untuk menangkap, memproses, dan menyusun kembali informasi visual atau verbal (Arsyad, 2002). Menurut Rohani (1997) media adalah segala sesuatu yang dapat diindra yang berfungsi sebagai perantara/sarana/alat untuk memproses komunikasi (proses pembelajaran). Menurut Sadiman dkk (1996) media adalah perantara atau pengantar pesan dari pengirim ke penerima pesan. Menurut Danim (1994) media pendidikan (pembelajaran) merupakan alat bantu atau pelengkap yang digunakan oleh guru atau pendidik dalam rangka berkomunikasi dengan siswa atau peserta didik.

Hamalik (dalam Arsyad, 2006) mengemukakan bahwa pemakaian media pembelajaran dalam proses belajar mengajar dapat membangkitkan keinginan dan minat yang baru, membangkitkan motivasi dan rangsangan kegiatan belajar, dan bahkan membawa pengaruh psikologis terhadap siswa.

Evie \& Lentz (dalam Arsyad, 2006) mengemukakan empat fungsi media pembelajaran, khususnya media visual, yaitu (a) fungsi atensi, (b) fungsi afektik, (c) fungsi kognitif, dan (d) fungsi kompensatoris. Fungsi atensi, yaitu menarik dan mengarahkan perhatian siswa untuk berkonsentrasi kepada isi pelajaran yang berkaitan dengan makna visual yang ditampilkan atau menyertai teks materi pelajaran. Fungsi afektif, dapat terlihat dari tingkat kenikmatan siswa ketika belajar (atau membaca) teks yang bergambar. Gambar atau lambang visual dapat menggugah emosi dan sikap siswa. Fungsi kognitif, terlihat dari temuan-temuan penelitian yang mengungkapkan bahwa lambang visual atau gambar memperlancar pencapaian tujuan untuk memahami dan mengingatkan informasi atau pesan yang terkandung dalam gambar. Fungsi kompensatoris, terlihat dari hasil penelitian bahwa media visual berfungsi untuk mengakomodasikan siswa yang lemah dan lambat menerima dan memahami isi pelajaran yang disajikan dengan teks atau disajikan secara verbal.

Kemps \& Dayton (dalam Arsyad, 2006) mengelompokkan media ke dalam beberapa jenis, yaitu :
a. Media cetakan
b. Media pajang
c. Overhead transparacies
d. Rekaman audio tape
e. Slide 
f. Film dan video

g. Televisi

h. Komputer

Dari penjelasan beberapa jenis media yang disebutkan di atas, dalam penelitian ini digunakan media kartu bergambar. Media kartu ini termasuk jenis media cetakan. Dengan media ini diharapkan siswa akan lebih mudah memahami macam-macam huruf Hijaiyah dan harakat.

Media kartu adalah media cetak yang terbuat dari kertas dengan tempelan gambargambar yang dikombinasi hingga menyerupai kartu permainan. Menurut Hamalik (1989) gambar yang digunakan sebagai media pendidikan akan berhasil dengan efektif, apabila disesuaikan dengan faktor kematangan anak, tujuan yang akan dicapai dan teknik penggunaan dalam situasi belajar. Di samping itu, media gambar relatif murah, mudah dimengerti, mudah dinikmati, dan dapat berfungsi untuk menyalurkan pesan melalui indera pengelihatan.

Manfaat media gambar adalah penyampaian dan penjelasan mengenai informasi, pesan, ide dan sebagainya dengan tanpa banyak menggunakan bahasa-bahasa verbal, tetapi dapat lebih memberi kesan (Rohani, 1997). Media kartu ini dibuat dari bahan kertas. pada kartu terdapat sebuah pertanyaan, dan jawaban yang berupa gambar-gambar menarik yang bervariasi. Media kartu inilah yang nantinya akan dipergunakan untuk membantu siswa dalam memahami bacaan dan macam-macam huruf hijaiyah dan harakatnya.

Ada berbagai macam permainan yang menggunakan kartu huruf sebagai alat mainnya diantaranya:

1) Permainan Mencari Huruf (Raisatun Nisak, 2012). Tujuan permainan ini adalah memudahkan anak dalam mengingat huruf abjad, melatih anak agar lebih tanggap, menumbuhkan rasa semangat belajar, dan memudahkan anak dalam menguasai dan memahami istilah/kata. Prosedur pelaksanaan permainannya adalah anak diajak untuk mencari huruf yang dapat membentuk sebuah kata yang melambangkan gambar yang ditunjukkan guru. Oleh karena itu dalam permainan ini diperlukan cukup banyak huruf agar anak tidak kebingungan karena huruf yang dicarinya tidak ada/habis.

2) Permainan Mencocokkan Huruf (Depdiknas, 2011). Pada permainan ini anak bertugas mencocokkan huruf sesuai dengan gambar dan tulisan yang ditunjukkan guru. Alat dan bahan yang digunakan adalah gambar yang dibawahnya terdapat nama gambar serta kartu huruf.

\section{Langkah-Langkah Penggunaan Media Kartu Permainan}

Merujuk dari permainan yang dikemukakan oleh Slamet Suyanto (2005), Raisatun Nisak (2012) dan Depdiknas (2011) tersebut maka penelitian ini kemudian mengembangkan permainan kartu huruf sebagai berikut. 
a) Guru mengambil sebuah kartu huruf, kemudian diperlihatkan pada anak-anak

b) Guru mengucapkan simbol huruf yang tertera pada kartu huruf, kemudian anak-anak diberi kesempatan untuk meniru mengucapkan simbol huruf tersebut.

c) Guru membalik kartu huruf, kemudian menyebutkan gambar yang tertera pada kartu huruf lalu menyebutkan pula hurufnya, dan anak-anak juga diberi kesempatan untuk meniru, mengucapkan.

d) Anak-anak diajak mempraktikan permainan kartu huruf secara bersama-sama

e) Setelah anak-anak bermain bersama-sama guru memberi kesempatan pada setiap anak untuk melakukan permainan kartu huruf secara individu.

Menurut Sudjana (1989) hasil belajar diartikan sebagai kemampuan yang dimiliki siswa setelah ia menerima pengalaman belajar. Hasil belajar merupakan kemampuan yang dimiliki siswa yang ditunjuk melalui perubahan tingkah laku setelah mengalami pengalaman belajar, misalnya perubahan dari tidak tahu menjadi tahu atau dari tidak mengerti menjadi mengerti. Dalam penelitian ini, hasil belajar diperoleh melalui tes yang dilaksanakan pada ahir pembelajaran. Apabila hasil tes siswa mencapai nilai KKM yaitu 75, maka dapat dikatakan bahwa pembelajaran tersebut berhasil. KKM adalah kriteria ketuntasan minimum yang harus dicapai oleh siswa per mata pelajaran. Siswa yang belum mencapai KKM dikatakan belum tuntas belajar.

\section{Tujuan Penelitian}

Tujuan penelitian ini adalah:

a. Untuk mengetahui pengunaan media kartu permainan dalam pembelajaran Membaca Huruf Hijaiyah dan Harakat Pada Siswa Kelas I SD Muhammadiyah I Panji Kabupaten Situbondo Pada Semester Genap Tahun Pelajaran 2018/2019.

b. Untuk mengetahui bagaimana peningkatan hasil belajar Membaca Huruf Hijaiyah dan Harakat Pada Siswa Kelas I SD Muhammadiyah I Panji Kabupaten Situbondo Pada Semester Genap Tahun Pelajaran 2018/2019.

\section{Manfaat Penelitian}

Penelitian tindakan kelas ini diharapkan memberi manfaat yang berarti bagi siswa, guru dan sekolah.

a. Bagi siswa

Siswa memperoleh motivasi belajar sehingga lebih giat belajar serta dapat menemukan, mengerti dan memahami bacaan huruf hijaiyah.

b. Bagi guru

Meningkatkan kreativitas guru dalam memanfaatkan benda-benda untuk dijadikan media pembelajaran yang menarik.

c. Bagi sekolah 
Memberi kontribusi yang lebih baik pada sekolah dalam rangka perbaikan pembelajaran khususnya pada mata pelajaran Pendidikan agama dan budi pekerti.

\section{Metode Penelitian}

Penelitian ini merupakanPenelitian Tindakan Kelas (PTK). Penelitisebagai inovator dalam memberikan solusi permasalahan di kelas. Tujuannya untuk memecahkan permasalahan pembelajaran yang kerap terjadidi kelas.Kemmis dan Mc. Taggart yang alur penelitiannya meliputi beberapa langkah: Action, Observasi dan Releksi/analisis (Reflection). Metode pengumpulan data adalah cara yang dapat digunakan untuk mengumpulkan data (Arikunto, 2002:126). Metode yang digunakan dalam penelitian ini adalah: (1) Observasi, (2) Dokumentasi, (3) Wawancara, (4) Tes.

\section{Hasil Penelitian}

Penelitian ini bertujuan untuk meningkatkan kemampuan membaca siswa dengan menggunakan metode permainan kartu huruf. Pelaksanaan penelitian ini dilakukan dengan beberapa tahap. Adapun tahap-tahap dalam penelitian ini dapat diinterpretasikan sebagai berikut:

Pada tahap Prasiklus Berdasarkan hasil observasi aktivitas belajar siswa pada prasiklus diketahui presentase aktivitas siswa secara klasikal sebesar $57 \%$ atau hanya terdapat 13 siswa yang tuntas, sedangkan siswa yang tidak tuntas sebanyak 10 siswa atau $43 \%$, hal tersebut menunjukkan bahwa aktivitas siswa dalam membaca huruf hijaiyah masih rendah. Dalam pembelajaran tahap prasiklus ini siswa hanya dapat mengelompokkan dan menyebutkan sedikit huruf hijaiyah sesuai harakatnya.

Kegiatan siklus I dilaksanakan pada hari rabu, tanggal 17 April 2019. Pembelajaran huruf hijaiyah berharokat fatha, domma dan kasro. diketahui presentase aktivitas siswa secara klasikal sebesar $78 \%$ atau terdapat 18 siswa yang tuntas, sedangkan siswa yang tidak tuntas sebanyak 5 siswa atau $22 \%$, hal tersebut menunjukkan bahwa aktivitas siswa dalam membaca huruf hijaiyah telah meningkat. Dalam pembelajaran tahap siklus 1 ini siswa sudah dapat mengelompokkan dan menyebutkan huruf hijaiyah sesuai harakatnya.

Pembelajaran membaca huruf hijaiyah dengan menggunakan media kartu huruf berharokat fatha domma dan kasro terdapat beberapa siswa yang masih mengalami kesulitan, beberapa kesulitan yang dialami siswa antara lain: a) masih kesulitan membedakan huruf yang mirip antara tsa, sya, dho dan dzo b) beberapa siswa masih membaca dengan terbata-bata, d) beberapa siswa tidak berani membaca didepan kelas, e) siswa membaca dengan sangat pelan sehingga tidak jelas pengucapanya. Berdasarkan data awal yang diperoleh dari hasil tes siklus 1, maka disusunlah rencana pembelajaran pada tahap siklus 2 yang nantinya dapat meningkatkan kemampuan membaca huruf 
hijaiyah. Melalui rencana pembelajaran ini diharapkan siswa dapat mengikuti kegiatan pembelajaran dengan baik serta menjadi aktif dalam kegiatan pembelajaran. Siswa yang masih belum berhasil memenuhi Kriteria Ketuntasan Minimal (KKM) yaitu 75, diharapkan mampu mencapai KKM yang sudah ditentukan.

Pembelajaran membaca dengan menggunakan kartu huruf hijaiyah secara keseluruhan dengan melihat hasil siklus II yang meningkat dan indikator keberhasilan penelitian ini sudah tercapai, maka penelitian ini dihentikan sampai siklus II. Berikut nilai dari siklus II. Semua siswa telah mencapai nilai Kriteria Ketuntasan Minimal (KKM) sebanyak 23 siswa dengan presentase $100 \%$, Berdasarkan keterangan diatas, presentase siswa pada prasiklus yaitu 57\% dengan kategori sangat kurang, siklus I yaitu 78\% dengan kategori Cukup Baik dan pada siklus II yaitu 100\% dengan kategori Sangat Baik, Dengan demikian presentase semakin meningkat.

Tabel 1. Perbandingan Hasil Tindakan Prasiklus ,Siklus I dan Siklus 2

\begin{tabular}{cccc}
\hline \multirow{2}{*}{ Kelas } & \multicolumn{3}{c}{ Presentase siswa yang mencapai nilai } \\
& KKM & \\
\cline { 2 - 4 } & Prasiklus & Siklus I & Siklus II \\
\hline I & $57 \%$ & $78 \%$ & $100 \%$
\end{tabular}

\section{KESIMPULAN DAN SARAN}

\section{Kesimpulan}

Menggunakan metode permainan kartu huruf dalam proses pembelajaran dapat meningkatkan kemampuan membaca huruf hijaiyah dan harakat pada mata pelajaran baca tulis Al-Quran kelas I Sekolah Dasar Muhammadiyah 1 Panji. Hal ini dibuktikan dengan adanya peningkatan rata-rata mulai prasiklus sampai siklus II. Pada saat prasiklus masih belum diberi tindakan yaitu pembelajaran membaca huruf hijaiyah dan harakat menggunakan metode permainan kartu huruf presentase ketuntasan belajar klasikal mencapai $(57 \%)$.

Pada siklus I diberi tindakan dengan menggunakan metode permainan kartu huruf dalam proses pembelajaran membaca huruf hijaiyah, presentase ketuntasan klasikalnya sebesear (78\%). Hal ini sudah mencapai kriteria ketuntasan minimal klasikal yaitu $75 \%$. Akan tetapi perlu meningkatkan lagi dengan melaksanakan siklus II sebagai tindakan perbaikan. Pada siklus II dilakukan perbaikan yaitu ketika guru memberikan tugas, guru memberikan bimbingan secara individu. Dilihat dari hasil presentase ketuntasan belajar klasikal yaitu 100\%. Pada siklus II hasil yang diperoleh sudah mencapai kriteria ketuntasan minimal klasikal. 


\section{Saran}

Berdasarkan hasil penelitian tentang peningkatan kemampuan membaca permulaan siswa kelas I SD Muhammadiyah 1 Panji, dikemukakan saran-saran sebagai berikut bagi guru diharapkan menggunakan metode dan media pembelajaran yang menarik pada waktu memberikan materi membaca salah satunya menggunakan metode permainan dengan media kartu huruf. bagi peneliti lain. Penelitian ini dapat dijadikan sebagai perbaikan untuk penelitian untuk penelitian lebih lanjut sehingga kekurangan dalam penelitian ini dapat teratasi.

\section{Daftar Pustaka}

2006. Media Pembelajaran. Jakarta: PT Raja Grafindo Persada.

Arikunto, S. 2002. Prosedur Penilaian Pendekatan Suatu Praktek. Jakarta: PT Rineka Cipta.

Arsyad, A. 2002. Media Pembelajaran. Jakarta: PT Raja Grafindo Persada.

Danim, S. 1994. Media Komunikasi Pendidikan. Jakarta: Bumi Aksara.

Depdiknas. 2006. Kurikulum Tingkat Satuan Pendidikan (Standar Kompetensi Mata Pelajaran Matematika SD). Jakarta: Depdiknas.

Hamalik, O. 1989. Media Pendidikan. Bandung : Citra Aditya Bakti.

Raisatun Nisak. 2012. Seabrek Games Asik-Edukatif untuk Mengajar. Jogjakarta:DivaPress

Rohani. 1997. Media Intsruksional Educatif. Jakarta: PT Rineka Cipta.

Sadiman A. S, R. Rahardjo, A. Haryono dan Rahardjito., 1996. Media Pendidikan, Pengertian, Pengembangan, dan Pemanfaatannya. Jakarta: Pustekkom Dikbud dan PT. Raja Grafindo Persada.

Slameto. 1995. Belajar dan Faktor-faktor yang Mempengaruhinya. Jakarta: Rineka Cipta.

Sudjana, N. 1989. Penilaian Proses Hasil Belajar Mengajar. Bandung: Remaja Rosdakarya. 